\title{
Social cultural characteristics of fisherman communities in Tomini Bay
}

\author{
Lis M Yapanto, Arfiani Rizki Paramata, Sisca Abuba
}

\author{
Management of Aquatic Resources \\ Faculty of Fisheries and Marine Science \\ Gorontalo State University \\ Email: lizrossler@ung.ac.id
}

\begin{abstract}
This study aims to determine the socio-cultural characteristics of the fishing community in Kayubulan Village, Batudaa Pantai District, Gorontalo District, Gorontalo Province. This research was conducted from May to June 2020. Using a descriptive qualitative method with sampling using simple random sampling. The results of the research on the socio-cultural characteristics of the Kayubulan Village fishing community include: social organization activities of the Kayubulan Village fishing community, fishermen education level, fishing technology tools, number of families, additional business, fishermen status, mutual cooperation system, and belief system. In terms of fishing, the majority have used katinting boats, with fishing gear still using traditional fishing gear such as hand lines.
\end{abstract}

Keywords: Socio-Culture, Community, Fishermen, Kayubulan Village 
The fishing community is a part of Indonesian society that lives by managing the potential of fishery resources. Some people who live in the coastal area of fishing communities have their own social characteristics that are different from those who live in the mainland area (Alamsyah, 2016).

Coastal fishing communities are among those who are still underdeveloped and are in a marginal position. In addition, there are many dimensions of life that are not known to outsiders about the characteristics of coastal communities. They have different ways in the aspects of knowledge, beliefs, social roles, and social structures. Meanwhile, behind their marginalization, coastal communities do not have many ways of dealing with the problems that are present (Fatmasari, 2010).

In the social construction of communities in coastal areas, fishing communities are part of this social construction, although it is realized that not all villages in coastal areas have residents who work as fishermen. However, in coastal villages where most of the population works as fishermen, fish farmers, or aquatic cultivators, fishermen culture has a major influence on the formation of the cultural identity of coastal communities as a whole (Ginkel, 2007 in Chilmy, 2015).

Fisherman culture is closely related to an orientation towards the sea. An orientation includes actual attitudes and knowledge. It can be said that people who have an orientation to survive on marine resources, with their cultural elements or awareness of environmental, social, cultural conditions, are the types or cultural characteristics of fishing communities (Rahmatullah, 2016).

The characteristics that characterize the social characteristics of the fishing community are having a high work ethic structure, utilizing self-efficacy and optimal adaptation, being competitive and achievement-oriented, appreciative of expertise, wealth and success in life, openness and very high social solidarity of fishermen, socio-economic problems and The culture that has occurred in fishing communities from a long time ago until now fishermen have lived in a work organization from generation to generation has not changed at all (Alamsyah, 2016).

The condition of the fishing community or the coastal community is a group of people that is relatively left behind economically, socially (especially in terms of access to education and health services), and culturally compared to other community groups. The condition of coastal communities or fishing communities in various regions is generally characterized by several characteristics, such as poverty, socio-cultural backwardness, low human resources (Fatmasari, 2010).

Kayubulan Village is located in Batudaa Pantai District, Gorontalo Regency, Gorontalo Province. is a village location on the coast where the majority of the population works as fishermen. This means that people's lives really depend on how much fish catch in the sea. The sociocultural life of the fishermen community in Kayubulan village still prioritizes kinship and kinship, mutual cooperation and belief systems, so this is what makes the author want to conduct research on "SocioCultural Characteristics of Fishermen Communities in Kayubulan Village, Batudaa Pantai District, Gorontalo District, Gorontalo Province ".

The research objective was to determine the socio-cultural characteristics of the fishing community in Kayubulan Village, Batudaa Pantai District, Gorontalo District.

\section{RESEARCH METEDOLOGY}

The research was conducted in Kayubulan Village, Batudaa Pantai District, Gorontalo District. When this research was conducted from May to June 2020. For more details, the research location can be seen in Figure 1.

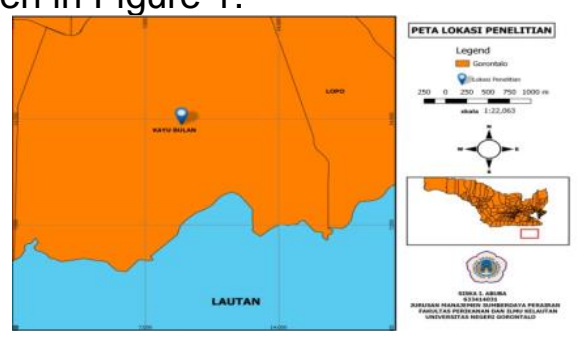

Figure 1 Map of Research Location: Kayubulan Village, Batudaa Pantai District, Gorontalo District. Source (Quantum Gis, 2020). 
Tools and Materials

The tools and materials used in this study can be seen in table 1 .

Table 1. Tools and Materials

\begin{tabular}{|c|c|c|}
\hline No. & $\begin{array}{l}\text { Types } \\
\text { of Tools and } \\
\text { Materials }\end{array}$ & Uses \\
\hline 1. & Camera & $\begin{array}{c}\text { As } \\
\text { documentation }\end{array}$ \\
\hline 2. & Stationery & $\begin{array}{l}\text { To record } \\
\text { results }\end{array}$ \\
\hline 3. & Questionnaire & $\begin{array}{c}\text { As an interview } \\
\text { guide }\end{array}$ \\
\hline
\end{tabular}

Source. Personal Documents, (2020)

\section{Data and Data Sources}

This research was conducted using qualitative descriptive data collection methods with data sources used including primary data and secondary data.

a) Primary data

Primary data namely data collection carried out to obtain data directly from the field. Primary data collection is done by:(Masri, 2010). In this study, primary data were obtained in several ways, namely as follows:

1. Observations of the results of observations / observations in this study are recorded descriptively, which accurately observes and records the phenomena that arise and knows the relationship between aspects of the phenomenon. The data and information can be in the form of quantitative and qualitative data tables, pictures and maps in the research area, as well as photo visualizations, as material for analysis and explanation.

The data taken in this study is data on socio-cultural characteristics, namely fishermen organizations, data the number of members of the fishermen's family, the condition of the fishermen's house, the level of fishermen's education, additional business, the status of the fishing community, the technology tools used, the mutual cooperation system (kinship and cooperation) and the belief system (customs, religion).

2. Interviewing, namely collecting data by doing direct communication to related parties and the public with regard to research usequestionnaire with closed questions where the answers have been determined as attached in attachment 1.

The respondents targeted in this research are the fishermen communities in Kayubulan Village, Batudaa Pantai District. The distribution of the questionnaire was carried out directly where the researcher used the questionnaire and directly interviewed the respondents.

b) Secondary Data

Secondary data is research data obtained by researchers indirectly through intermediary media or through related agencies (Cintra et al., 2017). In this study, secondary data were obtained from literature (journals and books), and through related agencies such as the Kayubulan Village office (Village Profile and data on the number of fishermen).

\section{Data Collection Procedure}

Before data collection is carried out, the first step that must be done is to determine the number of respondents using the simple random sampling method, namely simple random sampling, so that each population has the same opportunity to become a sample or represent the population ( Fathon 2005 in Watung et al, 2013). Respondents were drawn from 5 hamlets, namely: East Pentadu Hamlet, West Pentadu Hamlet, Padengo Hamlet, Apitalawo Hamlet, and Dunggala Hamlet, each totaling 13 people per hamlet.

In taking the sample, the amount must be representive so that later the results can be generalized. The samples to be taken in this study were determined as many as 65 people out of 185 fishermen (Kayubulan Village Profile, 2017). Sampling is determined using the Slovin formula (Simanjuntak, 2016):

$$
\begin{gathered}
\mathrm{n}=\frac{N}{1+\mathrm{Ne}^{2}} \\
\mathrm{n}=\frac{185}{1+185 \times 0,1^{2}} \\
\mathrm{n}=\frac{185}{1+1,85} \\
\mathrm{n}=\frac{185}{2,85} \\
\mathrm{n}=64,91 \text { (65 Respondents) }
\end{gathered}
$$

Information:

$\mathrm{n}=$ Sample size

$\mathrm{N}$ = sample population size 
$\mathrm{e}=$ Percentage of inaccuracy due to tolerable sampling error (tolerance degree of error sampling), namely $10 \%$ (0.01).

After obtaining the results from the number of samples or the number of respondents, then pThe process of data collection through primary data collection techniques and secondary data is carried out by means of observation and interviews.

\section{Data analysis}

The data and information that has been collected are processed using qualitative descriptive analysis. The data analyzed included the socio-cultural characteristics of the fishing community in Kayubulan Village, Batudaa Pantai District. According to Masri et al (2011), descriptive research is a method in research regarding the state of human status, an object, a set of conditions, a system of thought or a class of events in the present. Meanwhile, the purpose of this descriptive study is to load a systematic, actual and accurate picture or painting of the facts, characteristics and relationships between the phenomena of being investigated.

After the interview data was obtained, it was processed using Microsoft Excel. The first step is to create a table for each variable categorySocio-cultural characteristics, namely 1) fishermen organizations, 2) The level of education of fishermen, 3) Number of fisherman family members, 4) Condition of fishermen's house, 5) Additional business, 6) Status of fishermen community, 7) Fishing technology tools, 8) Mutual cooperation system, and 9) Trust system. Furthermore, the percentage of each category is visualized with a Pie chart.

\section{Research Location Overview}

Kayubulan Village is administratively located in the Batudaa Pantai District in Gorontalo Regency, Gorontalo Province. The geographic location of Kayubulan Village is in the coordinate range 122058'40.61 "East Longitude to 12300'38.25" East Longitude and 0029'5.19 "North Latitude to 0031'35.62" North Latitude. As for administratively
Kayubulan Village has the following boundaries

a. In the north, it is bordered by Pilolodaa Village Bay

b. To the south is bordered by Tomini

c. To the west is bordered by East Biluhu Village

d. The east is bordered by Lopo Village

Based on official spatial data from the Geospatial Information Agency (BIG) corrected by the participatory mapping method involving each hamlet head, it is known that Kayubulan Village has an area of \pm 2793 hectares. Kayubulan Village has a population of 2,656 people consisting of 1,366 men and 1,290 women. According to the level of education in Kayubulan Village, there are still 188 who have not graduated from elementary school, 998 people have graduated from elementary school, 282 have graduated from junior high school, 188 have graduated from high school and 77 people have graduated from tertiary education (Source: Village profile data in 2017).

Kayubulan village is a coastal area and its main product is from the sea. Because most of the population works as fishermen, besides that some also work as farmers, traders, civil servants, motorcycle taxi drivers, construction workers, entrepreneurs, and civil servants.

1. The Socio-Cultural
Characteristics of the Kayubulan Village
Fishermen Community
Based on the research results, the socio-cultural characteristics of the Kayubulan Village fishing community include: social organization activities of the Kayubulan Village fishing community, fishermen education level, fishing technology tools, number of families, additional business, fishermen status, mutual cooperation system, and belief system.

Kayubulan Village Fishermen Community Organization

According to Ulum, 2009: 53 in Fitriyah and Widodo (2010) Social organization is a network of human behavior in a complex scope in every society. the formation of a social organization at first due to the insistence of the interests and interests of individuals in society. these interests can 
be channeled through more orderly and formal forms of human fellowship.

In accordance with the theory above, that in general the formation of a social organization is initially due to the insistence of the interests and interests of individuals in society. these interests can be channeled through more orderly and formal forms of human fellowship.

The social organizations that are followed by fishermen are generally organizations related to their work as fishermen, as well as religious organizations. In general, fishermen join organizations because of certain objectives. The costs needed to go to sea are not small, starting from boats, fishing gear, fuel for engines, and so on. The uncertain income condition of fishermen causes fishermen to have limitations, both in terms of capital and other equipment that supports the fishing process. Therefore, these fishermen took the initiative to form an organization for the purposes of coordinating existing fishermen and to facilitate the interaction of fishermen with fishermen, as well as fishermen with the government.

Based on the explanation above, the results of research on the social organization of the Kayubulan Village fishing community can be seen in Figure 2.

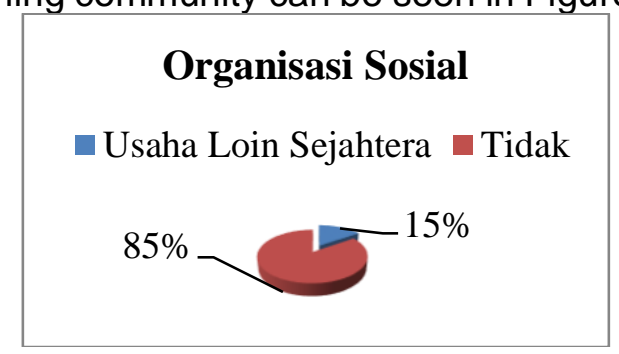

$$
\begin{aligned}
& \text { Figure 2. Fisherman Community } \\
& \text { Organization }
\end{aligned}
$$

(Source: Primary Data Processed, 2020)

Based on Figure 2, it can be seen that of the 65 fishermen respondents interviewed, only 10 fishermen (15\%) joined the Loin Sejahtera Business organization and fishermen who did not join the organization were 55 fishermen (85\%). The Loin Sejahtera Business Organization is a means of connecting fishermen with other fishermen, in this case fishermen who have capital. Meanwhile, religious organizations in the form of tahlilan, all fishing communities are involved in this activity where routine religion is carried out every time someone dies in their environment. With the aim that when one of them is hit by a disaster, someone will also pray.

\section{Education Level of the Kayubulan Village Fishermen Community}

In fishing business, the education level of fishermen is very low. This level of education is related to the use of technology in fishing (Sutanto, 2005).

Education is also a factor influencing productivity, educated respondents are more dynamic and active in seeking information related to technology and markets. Theoretically, the higher a person's education, the higher his ability to absorb technology, in this case is fishery technology (Oktary, 2012 in Hiola, 2017). The level of education of fishermen in Kayubulan Village can be seen in Figure 3.

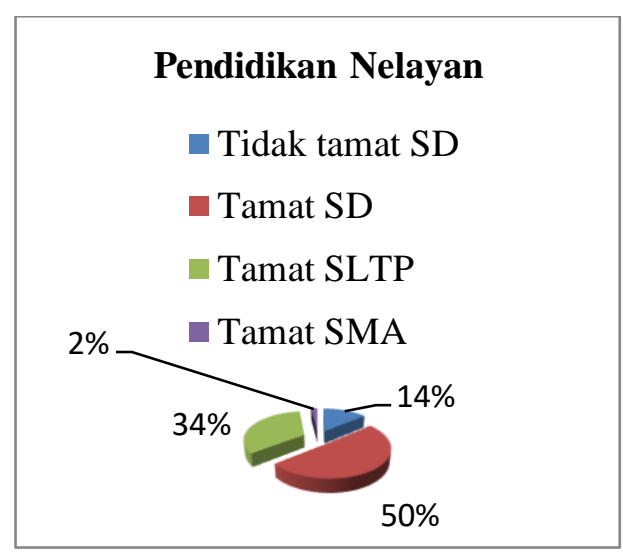

Figure 3. Education level of Kayubulan Village fishermen

(Source: Primary Data Processed, 2020)

Based on Figure 3 shows that the level of education of fishermen in Kayubulan Village mostly graduated from elementary school. If grouped based on the level of education that graduated from elementary school amounted to 33 people (50\%), 9 people did not complete elementary school (14\%), 22 people graduated from junior high school (34\%), and 1 person graduated from high school (2\%). This shows the low level of education of fishermen in Kayubulan Village due to a lack of awareness of the importance of education, besides the large amount of education costs incurred, and limited educational facilities. 


\section{Kayubulan Village Fishing Community Fishing Activities}

In fishing activities carried out by the fishing community, some are carried out in groups and some are carried out individually. Fishing that is carried out is very dependent on boats, suitable fishing equipment to operate, and a good season for fishing in order to have enough catches to meet the living needs of the fishing community. (Moha, 2021)

The catch landed from Tomini Bay from 1997 to 2002 was 87,500 tonnes per year, of which $42 \%$ were small pelagic fish. Small pelagic fish give the largest contribution in Gorontalo and Poso areas, especially from the catch of mini purse seine and chart. The dominant species caught is gliders (Decapterus spp). Malalugis species (D. macarellus) are the main target of fishing, contributing approximately $50 \%$ of the total catch, other types consist of flying fish, solutions, and selar or catombo. Pelagic fishing can be said to take place throughout the year, even in the western season. (December to February) fishing activity decreases for small fleets (5 to 10 GT). This unfavorable season condition (west season) also affects the Gorontalo fleet which has a larger fleet (10 to $10 \mathrm{GT}$ ). In general, the peak season for small pelagic fish in Tomini Bay takes place around the transitional season between the west to the east season (March) and from the east season to the east to west transitional season (Suwarso et al, 2007). This is the same as the catch of fishermen in Kayubulan Village, Batudaa Pantai District, the average types of fish caught are flying fish, mackerel, deho, and tuna fish.

Most of the fishing communities in Kayubulan Village use hand-line fishing rods, squid (totabito) and trawl fishing gear. Hand-line fishing gear is a fishing gear that is considered easier to operate and only consists of nylon rope, fishing line, and ladung (tin) as ballast so that the majority of fishermen in Kayubulan Village use the hand line fishing gear the most. Fish that are targeted for catching are tuna, mackerel, skipjack and deho fish. The boats used by fishermen are traditional boats (kating-ting boats) made of wood, measuring 6-7 m long, $60 \mathrm{~cm}$ wide and 80 $\mathrm{cm}$ high.
The catch of the fishing community in Kayubulan Village is mostly sold to collectors because the distance from Kayubulan Village to the Fish Auction Place is quite far. So, to save energy, they prefer to sell to collectors. However, some fishermen also sell their catch directly at the kayubulan market.

\section{The number of dependents}

The number of dependents in the family is the number of people who are covered or financed. The number of dependents will affect the business carried out because the more families that are covered, it will encourage someone to be more active in earning income (Indasari, 2017).

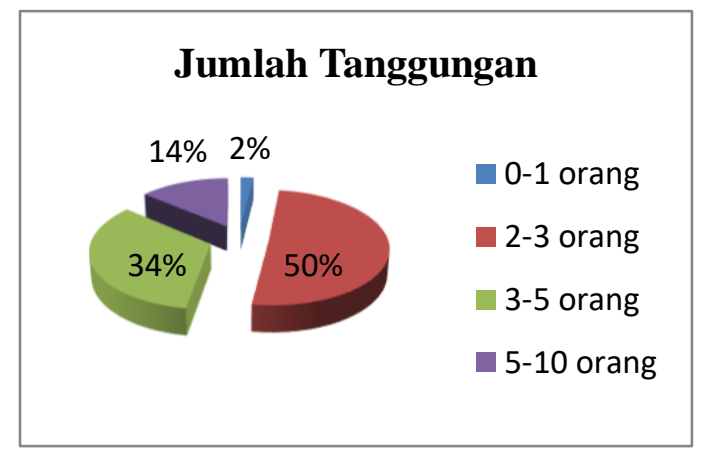

Figure 4. Number of Dependents for

Fishermen in Kayubulan Village

(Source: Primary Data Processed, 2020)

Based on Figure 4, it can be seen that the number of dependents of the Kayubulan Village fishermen's family, the number of dependents of $0-1$ is 1 person $(2 \%)$, while the number of dependents of 2 3 is 33 people ( $50 \%$ ), and in the number of dependents of $3-5$ are 22 people (34\%), for the number of dependents 5-10 amounted to 9 people (14\%).

\section{Side Job of Fishermen in Kayubulan Village}

The additional effort of the fishing community shows that their social status in the midst of the fishing community apart from the boss of their boat owners is not only a fisherman to fulfill their household needs. This is because some of the fishermen still feel a lack of the income they generate from fishing (fishermen). Therefore, apart from working as fishermen, they have additional businesses (Masri, 2010). 
Based on the results of interviews in the research of the Kayubulan Village fishing community who have a side job, it can be seen in Figure 5

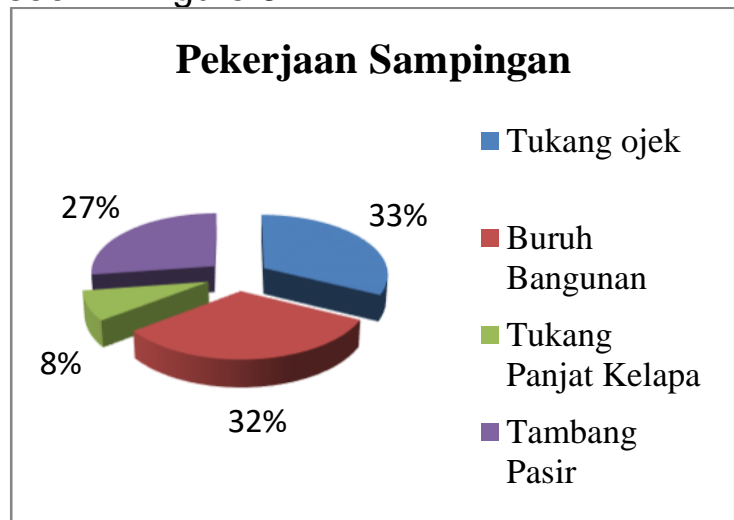

Figure 5 Side Job of Fishermen in Kayubulan Village

(Source: Primary Data Processed, 2020)

Based on Figure 5, it can be seen in the side jobs of the Kayubulan Village fishing community in the category of motorcycle taxi drivers amounting to 12 people (32\%), while those who work as construction workers are 12 people (32\%), and those who work as coconut climbers are 3 people $(8 \%)$, as sand miners amounted to 10 people (27\%). This shows that they do not only depend on work as fishermen because they still feel short of the income they make from fishing, while the respondents who do not have a side job are 28 people, this is because according to them the time to take a break from going to sea to return from fishing. very little to prepare fishermen to go back to sea.

\section{The Marital Status of the Kayubulan Village Fishermen Community}

Based on the results of the interviews conducted on the analysis of the cultural characteristics of the Kayubulan village fishing community when viewed from the marital status, it can be seen in Figure 6

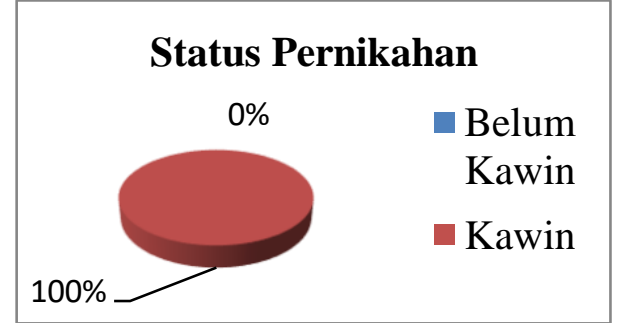

Figure 6. Marital Status of Fishermen in Kayubulan Village

(Source: Primary Data Processed, 2020)
Based on Figure 6, it can be seen that the level of status of the fishing community in Kayubulan Village is the highest, which is already married, amounting to 65 people (65\%) and those who are not married are $0 \%$.

\section{Length of Residence}

Based on the results of research interviews in the fishing community of Kayubulan Village, the category of long residence can be seen in Figure 7

\section{Lama Bertempat Tinggal}

- Sejak dari lahir $\quad$ Sejak Menetap

$25 \%$

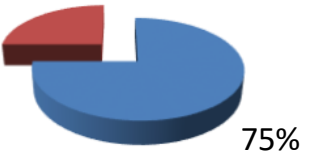

Figure 7. The length of residence of the fishermen in Kayubulan Village

(Source: Primary Data Processed, 2020)

Based on Figure 7, it can be seen that the fishermen in Kayubulan Village who have lived in the category since birth are 49 people $(75 \%)$ and the fishermen who have been living since they are 16 people (25\%). This shows that most of the fishing communities who live in Kayubulan Village are indeed indigenous people in the village, and those who are categorized as permanent fishermen are immigrant fishing communities who have established marital relationships with community members in Kayubulan Village and are working as fishermen.

\section{Kayubulan Village Fishermen's House Condition}

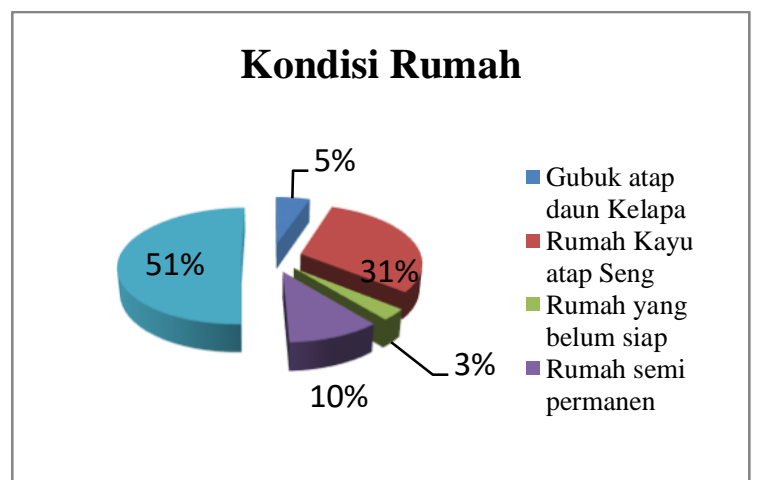

Based on Figure 8, it can be seen that the condition of the fishermen's houses in Kayubulan Village from 65 respondents whose house conditions are only coconut leaf-roof huts, amounting to 3 people (5\%), 
while those with tin roof wooden houses are 19 people $(30 \%)$, and the condition of the house is not yet. 2 people $(3 \%)$ had ready-made houses, 10 people $(11 \%)$ had semi-permanent houses and 31 people (51\%) had permanent houses. This shows that the conditions of the houses of the fishing community in Kayubulan village are generally in an irregular condition.

\section{Mutual Cooperation Between Fishermen}

Gotong royong activities are able to ease the burden on people who are less fortunate in daily life or residents who are affected by disaster, in other words if there are individuals who are less able to experience disaster or death, all of them are borne by the community in mutual cooperation (Apriani, 2009).

Based on the explanation above, it can be seen from the results of research on cooperation between fishermen in the Kayubulan Village community that can be seen in Figure 9.

\section{Kerjasama dengan Nelayan}

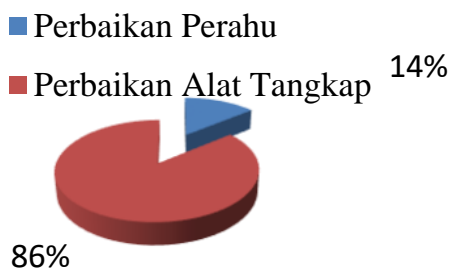

Figure 9 Cooperation between Fishermen in Kayubulan Village

(Source: Primary Data Processed, 2020)

Based on Figure 9, it can be seen that the collaboration between the fishermen of the Kayubulan Village community in boat repair is 19 people (14\%), while in the repair of fishing gear there are 56 people $(86 \%)$. This shows that the system of mutual cooperation between fishermen still exists from ancient times to the present. Not only that, the mutual cooperation activities are also carried out, namely when fishermen go out to sea, other fishermen help push the boat from the shoreline to the sea, then in the construction of a mosque the fishing community also participates in building a mosque. The majority of the people of Kayubulan Village are Muslim so they think that by doing gotong royong it can strengthen brotherhood and ease the burden between one individual and another.

\section{Certain Days Don't Go to Sea}

Based on the results of interviews, most of the fishermen in Kayubulan Village have knowledge of natural conditions that are not good for going out to sea. According to the fishermen, when the sky is dark at sea they do not go to sea because it is expected to rain and a storm will occur, so that it can endanger their safety. Not only that, the conditions of currents and waves are also considered by the fishing community in Kayubulan Village.

11. Customs that are carried out before going down to sea

Based on the results of interviews, on average, all fishermen in the customary Kayubulan Village who were carried out before going to sea were still the same as other fishing communities, namely they believed more in Allah's provisions by only having their intention and reading Bismillah when they went to sea. This belief is based on their belief in the Almighty. Besides that, the factor that must be considered in order to get the catch is the quality of the bait at the time of fishing.

\section{Abstinence that must be avoided at sea}

Based on the results of interviews on average, all the fishing communities of Kayubulan Village think that the taboo that must be avoided at sea is when fishing, in which case the fisherman is prohibited from speaking or Mohinggolabu (Wonder), besides that it is prohibited to say harshly according to them if the fisherman violates this taboo. they may not catch the fish while in the catch. As well as the family in the abandoned house should not make a fuss which will have a bad impact on them when they go to sea.

\section{Customs That Still Apply}

Based on the results of interviews with the fishing community of Kayubulan Village, there are 3 customs that are still valid from ancient times to the present, namely:

\section{New Boat Drop}

In the tradition of lowering a new boat or called the Mopolahu Lo Bulotu tradition, the fishing community of Kayubulan Village holds prayer prayers for the boats before they are used to go to sea. 
The tradition of lowering boats in Kayubulan Village begins with preparing necessities such as providing incense (Alama), a kettle that has been filled with water and leaves which people usually call Polohungo can be seen in Figure 10.

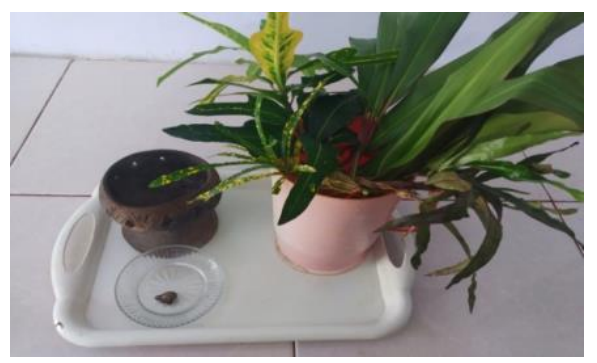

Figure 10. Materials used in the lowering of the boat

(Source: Private Doc, 2020)

Ngadi ShalawatiThis was led directly by the local imam, the prayers that were based on Islam were read, remembering that the fishing community in Kayubulan Village is predominantly Muslim, which has Islamic nuances of culture and traditions. After the recitation of the prayer is finished, the water is splashed on the boat which will be lowered from the bow to the rudder of the boat. The purpose of this tradition is to get a lot of sustenance and avoid calamities at sea.

\section{Reject Bala}

The fishing community in Kayubulan Village has a tradition, namely the "Reject Bala" ceremony which is held every 10 Muharam. This tradition has been carried out from ancient times to the present the Tolak Bala ceremony is carried out around the coast of Kayubulan Village which is led directly by local customary leaders can be seen in Figure 11.

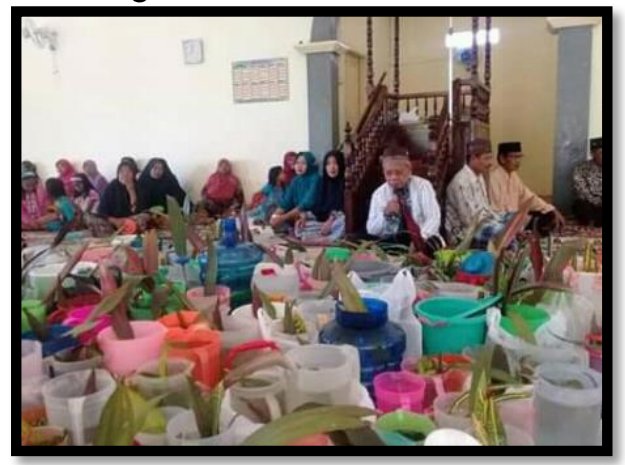

Figure 11. Prayer readings by traditional leaders

(Source: Personal Doc., 2020)
In this tradition, the people of Kayubulan Village bring a water kettle filled with Polohungo flowers which will be brought to the mosque for prayer and the water will be drunk or used for bathing by the people of Kayubulan Village. After that, it was followed by throwing stones at the customary leaders who were covered with mats who were riding in a fishing boat. The purpose of this tradition is to be kept away from the dangers that threaten the sea and it is believed to be able to help fishermen get an abundant catch.

\section{The tradition of the Prophet's birthday}

The tradition of the Prophet's birthday has been carried out since ancient times where the fishing community helped their wives in making Tolangga. Tolangga is made from pieces of bamboo that have been shaped into a cone, under which is made of wood that has been shaped inside which is decorated with kolombengi and sukade cakes. Can be seen in Figure 17

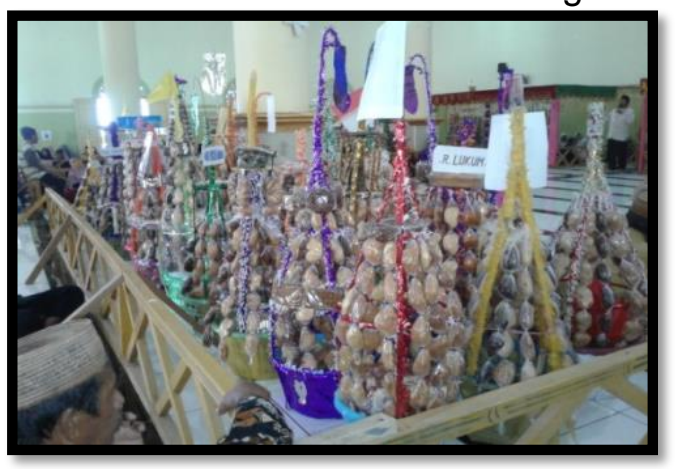

Figure 12. The Tolangga Tradition (Source: Personal Doc., 2020)

In this tradition the Kayubulan fishing community brings Telangga to the mosque to be prayed for then the telangga is distributed to the people who perform Dhikr at the mosque. The implementation of this tradition aims to show the fishermen's gratitude to the creator for the sustenance obtained from the abundant marine products.

\section{Conclusion}

Based on the results of the above research, it can be concluded that the socio-cultural characteristics of the fishermen community in Kayubulan Village, Batudaa Pantai District, in terms of fishing activities, the majority have used katinting boats, with fishing gear still using traditional fishing gear such as hand lines. and the 
culture that is still in effect, namely the mopolahu lo bulotu tradition (new boat people), the tradition of rejecting bala, and the tradition of the Prophet's birthday.

\section{Suggestion}

The need for further research for students, especially for the economic aspect of the Kayubulan village fishing community and for reference material for readers and as a reference for research on the socio-economic aspects of coastal communities.

\section{BIBLIOGRAPHY}

[1] Alamsyah, Grace. 2016. Social Solidarity with Fishermen Community in Catching Fish in Bentengnge Village, Ujungbulu District, Bulukumba Regency. Thesis. Ushuluddin Faculty of Philosophy and Politics Uin Alauddin Makassar.

[2] Baruadi, ASR, \& Yapanto, LM (2020). Supporting the capacity of coastal areas in North Gorontalo District. 8 (11), 1932-1941.

[3] Chilmy, WN 2015. Local Wisdom of Fishermen Community in Brakas Village, Ra'as District, Sumenep Regency. Journal. Vol. 2 No. November 2, 2015. Lecturer at the Faculty of Social and Political Sciences, Islamic University of Jember.

[4] Cintra et al., 2017. Analysis of Capture Fisheries Vulnerability Due to Climate Change at Provincial Scale. Coastal and Ocean Resources Management Study Program. Postgraduate School, Bogor Agricultural University.

[5] Fatmasari, D. 2010. Socio-Economic and Cultural Analysis of the Coastal Community of Waruduwur Village, Mundu District, Cirebon Regency. Faculty of Syraiah and Islamic Economics, IAIN Syekh Nurjati Cirebon.
Fitriyah Khoirotul, Widodo Djoko 2010. Socio-Cultural and Economic Characteristics of Small Fishermen in the Coastal Areas of Puger Wetan Village, Puger District, Jember Regency., Journal, Economics Study Program, Faculty of Teacher Training and Education, Jember University, Puger Wetan Village, Jember Regency

Hiola, F. 2017. Analysis of Fishermen's Income and Marketing Efficiency of Squid in Lamu Village, Batudaa Pantai District, Gorontalo District. Thesis. Department of Aquatic Resources Management. Faculty of Fisheries and Marine Sciences, Gorontalo State University

Indasari, Nur. 2017. Factors Affecting the Income Level of Outboard Motor Boat Fishermen in Tasamaju Village, Galesong Utara District, Takalar Regency. Thesis. Department of Economics, Faculty of Economics and Islamic Business, State University of Alauddin Makasar.

Masri, 2010. Identification of the Social, Economic, and Cultural Characteristics of the Sungai Limau Fishing Community in Padang Pariaman Regency in Providing Residential Housing. Thesis. Postgraduate Program in Regional and City Development Engineering at the University of Ponegoro Semarang.

Masri, Maryono, Yudi. B, Asnawi, M. 2011. Social, Economic, and Cultural Characteristics in Provision of Housing for the Sungai Limau Fishing Community, Padang Pariaman, West Sumatra. Journal of June 2011 Volume (1) 20-30 Master Program in Regional and City Development Engineering Postgraduate Program, Diponegoro University, Semarang, Central Java

Moha, Y. 2021. Study of Customs and Culture in Fishing in the Waters of Tomini Bay, Gorontalo Province. Thesis. Department of Aquatic Resources Management. Faculty of 
Fisheries and Marine Sciences, Gorontalo State University

[6] Rahmatullah, 2016. Religious Social Behavior of Fishermen Community in Baurung Village, Banggae Timur District, Majene Regency. Thesis. Faculty of Ushuludin and Philosophy, UIN Alauddin Makasar.

[7] Sutanto HA 2005. Efficiency Analysis of Gillnet and Cantrang Fishing Gear. Thesis. Economics Study Program and Development Studies. Diponegoro University. Semarang. http://eprints.undip.ac.id/15629/.

March 252018 . (14:15) new bibliography list

[8] Suharto, B., \& Yapanto, LM (2018). Participation of the Community in Management of Tourist in the Village of Torosiaje Sub District Popayato District of Pohuwato Gorontalo Province. 3 (8), 43-45.

[9] Suwarso, B. Sadhotomo, Wudianto. 2007. Small Pelagic Developments in Tomini Bay An Approach to Responsible Management. Journal. Research at the Research Institute for Marine Fisheries, Muara BaruJakarta and Research at the Capture Fisheries Iset Center, Ancol-Jakarta.

[10] Olii, AH, Yapanto, LM, \& Akili, SA (2019). The Efficiency Handline Fishing Gear in Gorontalo Regency, Indonesia. Asian Journal of Fisheries and Aquatic Research, 110.https://doi.org/10.9734/ajfar/2019/ v4i430061

[11] Watung, N., Dien, C. and Kotambunan, O. 2013. Socio-Economic Characteristics of Fishermen Communities in Lopana Village, Amurang Timur District, North Sulawesi Province. Journal of Acculturation. Volume 1, Number 2 October 2013

[12] Yapanto, L. M., Harahab, N., \& Olii, A. H. (n.d.). The Coastal communities and alternative income In Bone Bolango Regency, Gorontalo Province of Indonesia.

[13] Yapanto, L. M., Musa, D. T., Tanipu, F., \& Suherman, S. (n.d.). The Impact of Covid-19 on Supply Chain Fisheries and Challenges by Fisherman in Indonesia. 22(10), 1360-1365.

[14] Yapanto, L.M., Musa, F.T. (2018). Distribution of Seafood Production in Bajo Sector of Gorontalo Province Indonesia. International Journal of Innovative Science and Research Technology, 3(8). www.ijisrt.com521

[15] Yapanto, L. M., \& Olilingo, F. Z. (2020). The contribution of the fisheries and marine sectors to improving regional income. 22(10), 1307-1321.

[16] Muhaimin, A. W., Toiba, H., Retnoningsih, D., \& Yapanto, L. M. (2020). The Impact of Technology Adoption on Income and Food Security Of Smallholder Cassava Farmers: Empirical Evidence From Indonesia. 29(9), 699-706

[17] Setiawan, R., Pio, L., Cavaliere, L., Sankaran, D., Rani, K., Yapanto, L. M., Laskar, N. H., Raisal, I., Christabel, G. J. A., Setiawan, R., Petra, U. K., Airlangga, U., Pio, L., Cavaliere, L., \& Foggia, U. (n.d.). Access to Financial Services and Women Empowerment, through Microfinance eligibility. 1, 841-859. 